International Research Journal of Management, IT \& Social Sciences
Available online at https://sloap.org/journals/index.php/irjmis/
Vol. 6 No. 5, September 2019, pages: 9 16
ISSN: 2395-7492
https://doi.org/10.21744/irjmis.v6n5.657

\title{
Local Development Applied to Energy Scheme
}

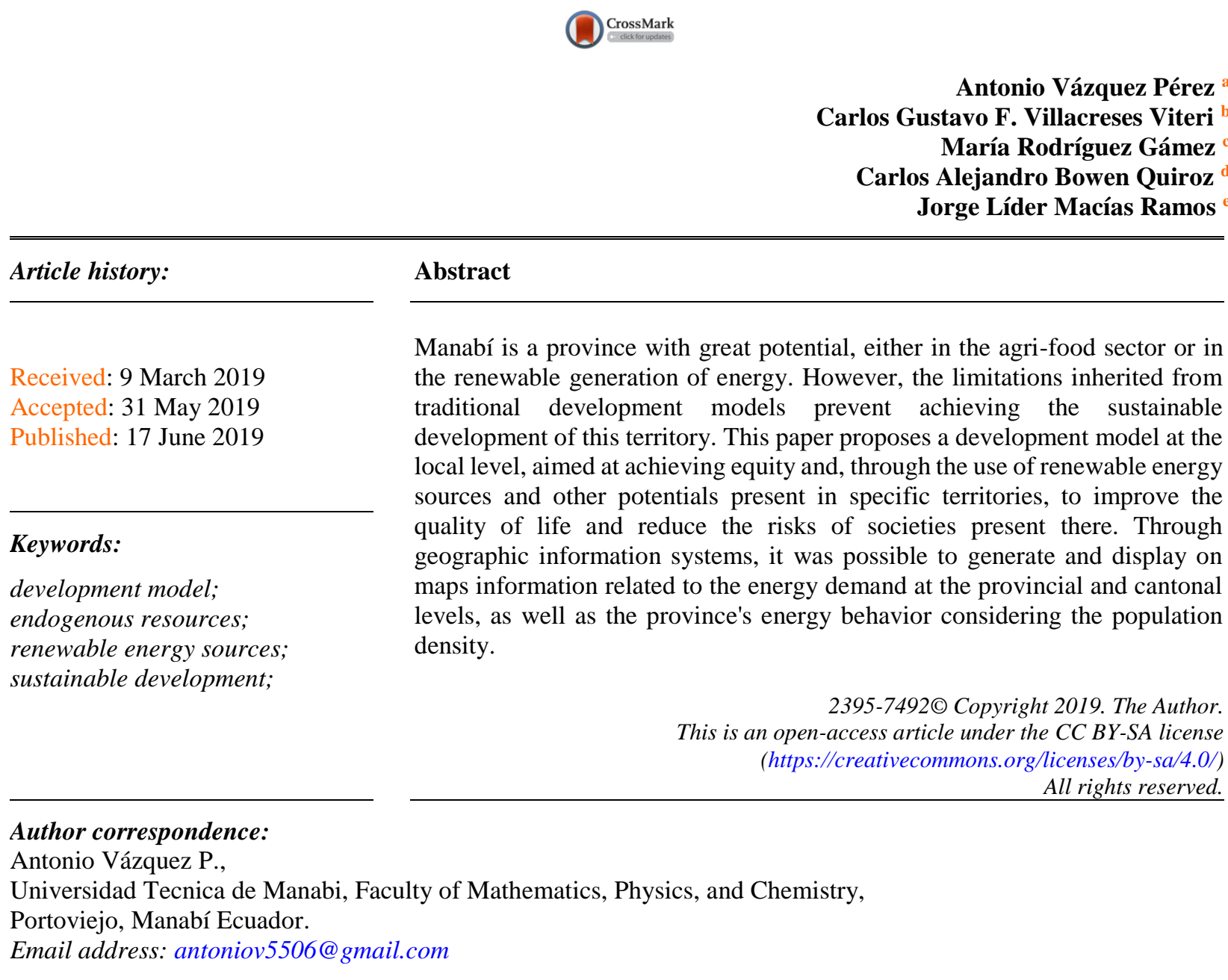

\section{Introduction}

Planning is essential in local development. The decision-making authorities must ensure the use of the natural resources and endogenous potential of the communities, through the organization of the financial resource, mainly.

Due to global pollution processes, caused mainly by the origin and use of energy, among other aspects, the international community is advocating local development. The potential studies of a specific territory and the possible beneficiary populations are an important starting point to achieve local development. Thus, communities become the main actors in this process (Cedeno et al., 2017; Chilán et al., 2018; Gamez et al., 2017).

${ }^{\text {a }}$ Universidad Tecnica de Manabi, Faculty of Mathematics, Physics and Chemistry, Portoviejo, Manabí Ecuador

${ }^{\mathrm{b}}$ Universidad Tecnica de Manabi, Faculty of Mathematics, Physics and Chemistry, Portoviejo, Manabí Ecuador

${ }^{c}$ Universidad Tecnica de Manabi, Faculty of Mathematics, Physics and Chemistry, Portoviejo, Manabí Ecuador

${ }^{\mathrm{d}}$ Universidad Tecnica de Manabi, Faculty of Mathematics, Physics and Chemistry, Portoviejo, Manabí Ecuador

${ }^{\text {e }}$ Universidad Tecnica de Manabi, Faculty of Mathematics, Physics and Chemistry, Portoviejo, Manabí Ecuador 
The planning and territorial planning are an instrument of transparency. It can has used as an administrative tool, providing the technical possibilities for intervention in the territory (Rodríguez et al., 2017). They also allow determining the different parameters that, in energy matters, affect each territory. In this way, it has sought that the decision making regarding the usable natural resources tends to improve the efficiency and, therefore, the use of these resources. This approach is not only valid for renewable sources; but also for the implementation of investments related to the exploitation of fossil fuels and the evaluation of their environmental impacts (Meza et al., 2018; Perez 2017).

The relationship and integration of renewable energies to the processes of planning and territorial ordering arise from a need, to have developed strategies, with a comprehensive perception, improving the living conditions of the population and the development of the territories (Irusta, 2016).

The close link between environmental and energy issues has supported by local discourses and international agreements that address their comprehensive treatment in various spheres and territorial scale. The inclusion of environmental and energy issues in the development of public policies is considered a strategy and demand for increasingly prospective and effective planning processes. In this sense, renewable energies and energy efficiency measures emerge as a viable response to change (Belmonte et al., 2009).

The province of Manabí is an area rich in agricultural products and has the largest coastal area of Ecuador. These characteristics make it a territory rich in different types of waste, coming from the productive and industrial processes (Daily The Telegraph, 2016).

The Constitution of the Republic of Ecuador, in its Art. 413.-, states: "The State will promote energy efficiency, the development and use of environmentally sound and healthy practices and technologies, as well as renewable, diversified, low impact energies, and that they do not put at risk food sovereignty, the ecological balance of ecosystems or the right to water " (Constituent Assembly, 2008).

Given that Ecuadorian laws, seek to promote sustainable development. In the 2014 Annual Operative Plan of the provincial government of Manabí, the vision of manzanitas has proposed to convert the province into a center of connectivity, maritime and air transfer of the South Pacific, greater fishery, agricultural, artisanal and tourist producer of the Ecuadorian coast. Provider of energy and water resources for the region, promoter of social inclusion and rescue of the Manabí cultural identity, in harmony with nature for Good Living and its social integration and policy (GADP, 2014). In this plan, it is planned to offer the necessary energy resources to enhance the proposed development, but most of the energy produced in the province comes from fossil fuels (MEER, 2014).

In Manabí, the diversification of energy sources is limited, despite the fact that this territory has renewable natural resources that have exploited through power generation systems connected to the grid, thus improving the quality of the electricity supply, or through isolated systems, in function to achieve the total electrification in the territory of the province. In this context, one can work with a single type of renewable energy source or, through hybrid systems, combine the potentials, mainly to supply rural areas (Rodríguez et al., 2015).

The current energy scheme needs to has restructured, especially in rural areas. The diversification of energy sources and distributed generation must be the axis of this restructuring. In this way, it would substantially improve the quality of service, efficiency and the reduction of losses. The goal of adequately combining the technical options available at the territorial level, taking advantage of indigenous sources and favoring the preservation of natural resources and environmental respect, would be achieved (Rodríguez et al., 2017).

\section{Materials and Methods}

Based on the premise that the province of Manabí is one of the main contributors to the agri-food sector of Ecuador. That its potential for solar radiation is high, that it is one of the provinces with the highest poverty rates and that it has limitations in the provision of basic services to its population, deductive and analytical-descriptive methods have used to interpret. The province's energy potential and the role that local development takes in the equitable progress of the territories and the improvement of the conditions of life of the Manabí society, from the use of renewable energy sources.

\section{Results and Discussions}

\section{Renewable energy sources in the province of Manabi}

The main source of energy in the province of Manabí is solar radiation. Currently, it has known that solar radiation that affects the Manabí territory is equivalent to half a liter of oil per square meter per day, considering the conversion 
capacity of silicon cells in photovoltaic panels. There are technologies, such as the aforementioned panels, that make it possible to take advantage of this resource efficiently. In addition, by not needing fossil fuels, generation through photovoltaic panels is free of COemissions 2 .

In addition to the solar potential that, in general terms, is present throughout the province, there are also defined sites that have the potential to generate wind and hydraulic energy. Exploit these potentials chasing through distributed generation, solving the lack of electric service in many rural territories of the province.

Another important potential is that of biomass. In the province are located plantations that have used, as a crop or through their products or waste, to produce biofuels and generate energy. In terms of energy, the most important plantation is that of the pinon (Jatropha curcas) whose fruits are extracted biodiesel of good energy quality that meets $10 \%$ of the generation of the Galapagos Islands (IICA, 2015).

The cultivation of Jatropha curcas protects and preserves the soil. It can be grown anywhere in the province since it can grow on any type of terrain, including sandy and stony soils. Its deciduous leaves constantly enrich the soil, making it more fertile. It is a plant with a tropical and subtropical climate, although it can withstand low temperatures. It requires little water and resists long periods of drought, defoliation to reduce perspiration. All these characteristics make pinion an attractive crop for the massive production of biofuel.

Figure 1 shows a map of the province of Manabí with the parishes where pine nut seeds are currently collected for biofuel production.

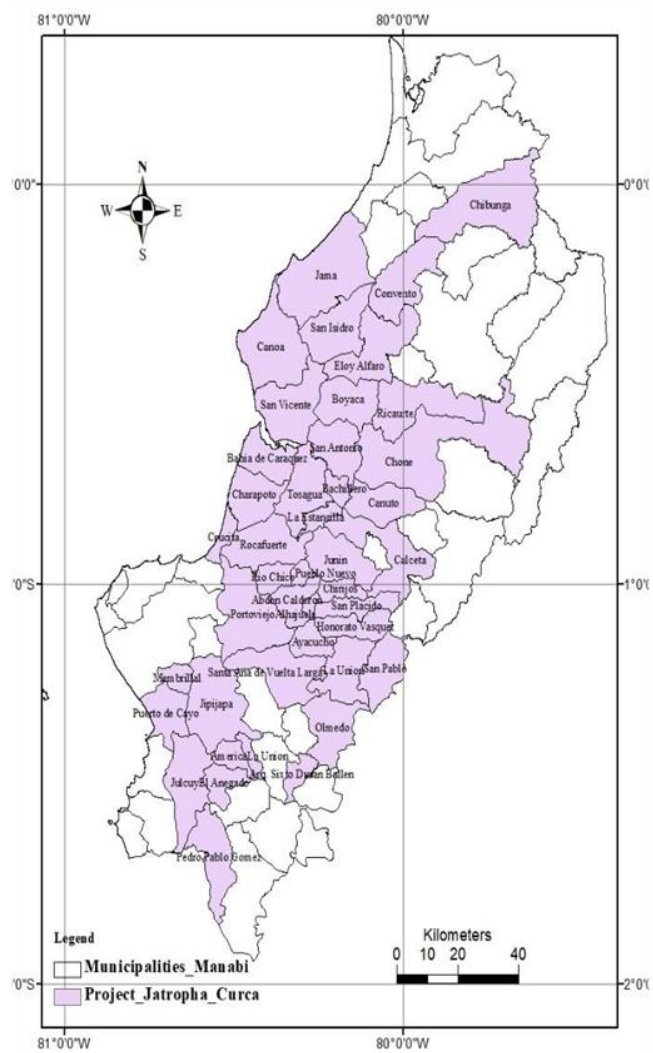

Figure 1. Parishes where seeds are grown and harvested Jatropha curcas for biofuel production (García et al., 2017). In studies carried out in 2016, it was possible to verify that the province of Manabí is the largest area dedicated to agricultural work; with 765,625 ha dedicated to cultivated and natural pastures (INEC, 2016). According to this same source, the cattle lead the livestock sector with 4.13 million heads, being the third province in rice production, second producer of corn, with an annual banana production that represents $39.76 \%$ of all the country, besides having teak and cane. Transform all these lines contribute to the generation of waste that has into some type of energy. In addition, domestic solid waste that has burned or buried today can also have considered as a possible source of energy generation.

Pérez, A. V., Viteri, C. G. F. V., Gámez, M. R., \& Ramos, J. L. M. (2019). Local development applied to energy scheme. International Research Journal of Management, IT and Social Sciences, 6(5), 9-16. 


\section{Proposed model for local development}

Assessing has dispersed resources available in the territory; it is possible to propose a strategy to achieve energy sustainability through the introduction of a local development model that encourages the use of the territory's energy resources.

The development models that have traditionally been applied, despite having contributed to the progress of society, have not managed to solve the phenomenon of poverty, lack of equity, access to quality educational and health services for more than 30 years. \% of the world population, a phenomenon that does not escape Ecuador and especially the province of Manabí, which classifies it as one of the poorest territories in the country.

Currently, the new poverty lines bring the number of poor people to approximately 3,400 million, from 760 million under the old World Bank measure. In other words, poverty, far from diminishing, shows a tendency to increase. Nearly half of the world's population lacks comprehensive access to basic health services; 1.1 billion people do not have access to quality energy services; 58 million children between 6 and 11 years old are out of school; 663 million people do not have access to drinking water and in Latin America, they are 37 million. The United Nations (UN) estimates that, in the world, some one billion people live in slums, in an environment where crime and drug addiction have presented. These evils are gaining more and more space, coming to recognize by the UN itself that in the current conditions there is a direct relationship between development and environmental pollution. All this shows that it would be very difficult to achieve the sustainability of development, clinging to the traditional models of social progress.

The proposed new development model was based on the use of endogenous resources, the decentralization of planning processes and the allocation of resources, considering it as a process that must have carried out from the bottom up, although it considers the coexistence with certain elements of the traditional development scheme.

In this way, the local development model was based on a system where the factors of the locality are empowered by the social destiny of its territory, its natural resources and the government provides all the support for the system to has carried out in a harmonious way with the strategic interests of the country's development. Community social groups plan the management of endogenous resources, thus achieving the opening of new production capacities and the aggregation of values to traditional production, which becomes a powerful potential for generating new jobs, improving activity economic, improvement of the small energy company with the emergence of new alternative industries that take advantage of the resources of the community.

These results allow them to maintain a favorable environment for the transfer of knowledge and technology, and new institutions can emerge at the local level that will have closely linked to community development and respond to the use of endogenous resources.

With the proposed results, it would be possible to improve the quality of life and with it, the increase in the degree of social welfare, the dependence on the outside has reduced and an advantageous exchange between the localities can have achieved.

At the same time, growth and job creation can have achieved, reinforcing the collective spirit, the social culture and the preservation of the environment. Figure 2 shows the model for energy decentralization within the framework of sustainable local development.

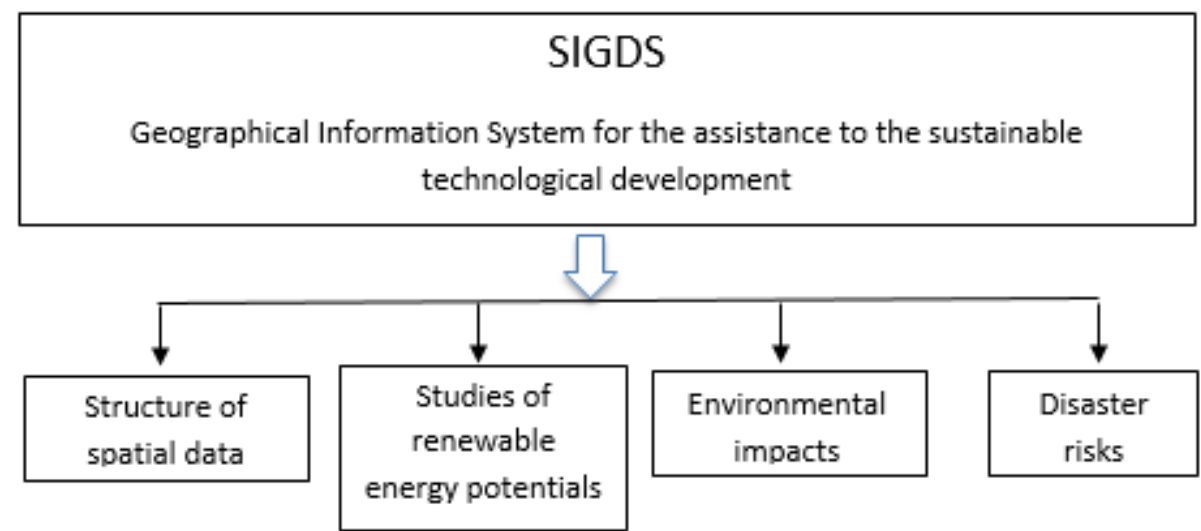

Figure 2. Model for energy decentralization and sustainable local development 
The incorporation of environmental variables and integration into the decision-making process for energy management imposes a requirement to move towards the decentralization of the processes of study and experimentation, aimed at the full development of the territories, establishing and consolidating the administrative competence for territorial proposals within the framework of local development.

The basic objective of decentralization policies is to ensure that localities can take charge of the destination of resources, under criteria of energy and food self-sufficiency, putting local interests at stake; but without contradicting the macro objectives of a sustainable and integrated national development. The aim is to introduce new spatial planning schemes, for which the criteria of sustainable development are fundamental in the short, medium and long term. These schemes can benefit from the use of Geographic Information Systems.

The province of Manabí is among the provinces of Ecuador that have the highest per capita energy consumption. Figure 3 shows two maps elaborated on a chromatic scale, which allow comparatively appreciate: in "B" the ratio of the per capita electricity consumption of the province of Manabí in relation to the rest of the provinces of the country and in " $\mathrm{A}$ " the ratio of per capita electricity consumption in the cantons of the province.

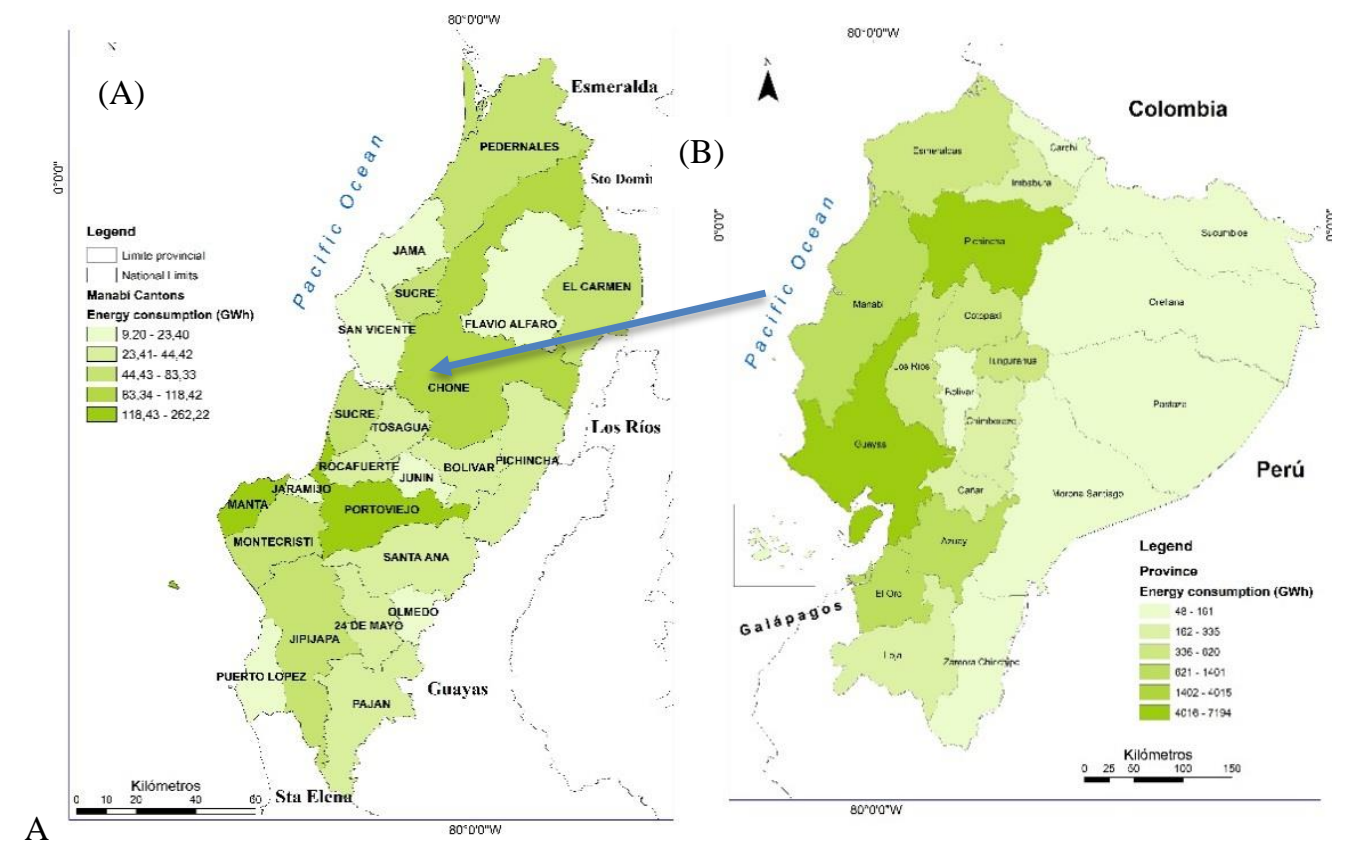

Figure 3. Maps of the ratio of per capita electricity consumption in Ecuador (B) and in the province of Manabí (A).

It can have seen that the province of Manabí is among the three provinces with the highest per capita electricity consumption in the country and that at the province level. The highest per capita consumption of electricity is concentrated in three municipalities: Portoviejo, where the capital city is located; Manta, which is a port city with an important industrial component; and Chone. In these municipalities, the highest levels of demand are also concentrated. If we compare the demand levels with the population density of the province, we will notice that, as shown in the map of figure 4, in the Manta and Portoviejo cantons, where the highest population density is concentrated, there is the greatest demand of energy.

Pérez, A. V., Viteri, C. G. F. V., Gámez, M. R., \& Ramos, J. L. M. (2019). Local development applied to energy scheme. International Research Journal of Management, IT and Social Sciences, 6(5), 9-16. 


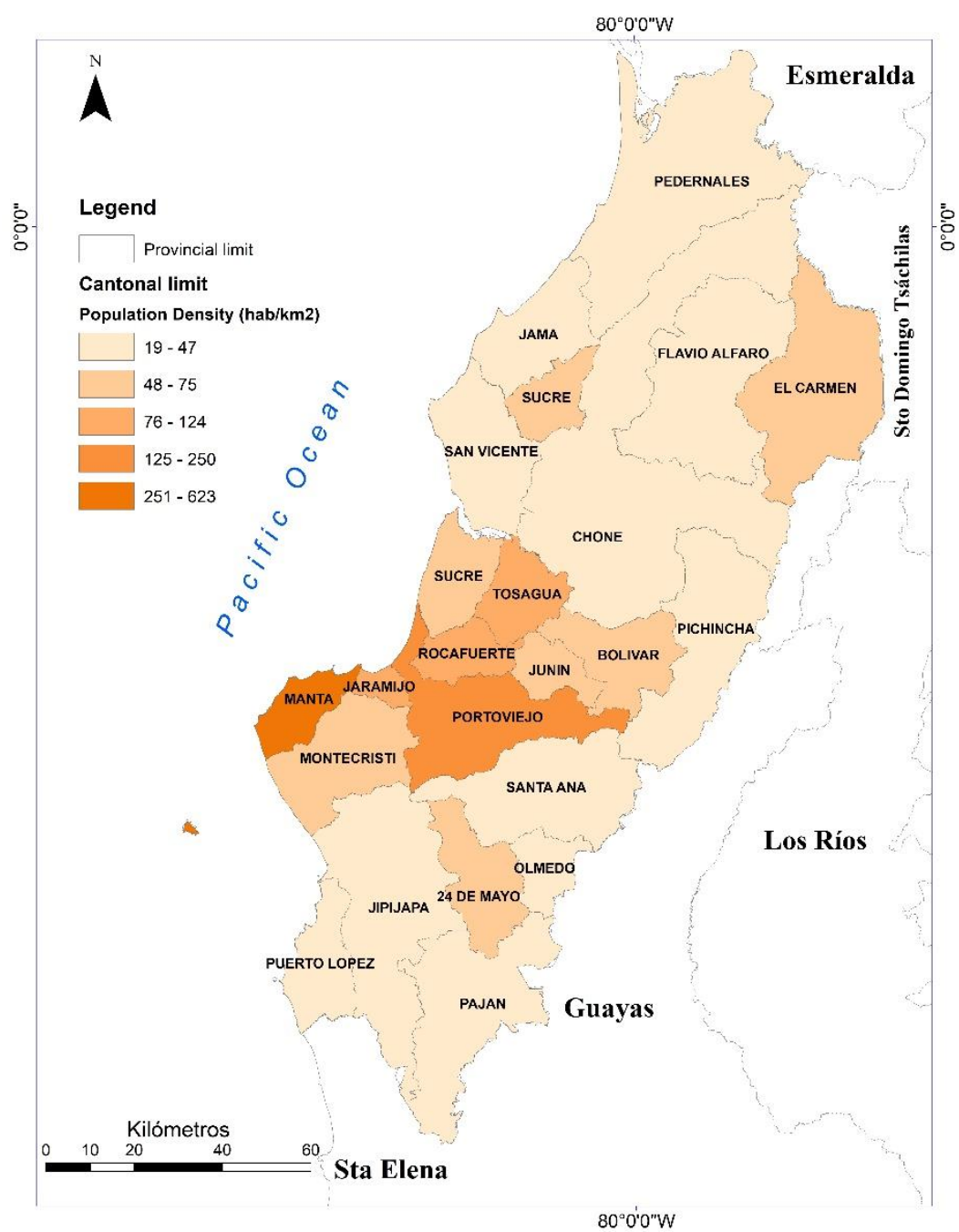

Figure 4. Population density by cantons in the province of Manabí

The analysis carried out previously shows the close relationship that exists between the population density, the demand and the consumption of electrical energy, but when speaking of local development in the energy area. One should think about the endogenous resources that the localities have, which they can has used to reduce oil consumption and at the same time contribute to preserving environmental conditions.

\section{Conclusion}

The investigation showed that the province of Manabí has sufficient availability of renewable energy sources to sustain its energy development in the use of its natural resources. It was determined that, for the province of Manabí, it will be very difficult to achieve the sustainability of development from the traditional models of economic and social progress, being necessary to undertake the gradual and progressive introduction of local development models, in such a way that reduces dependence on the outside, although for certain activities it is considered.

The need for support from the Ecuadorian state in order to get the province of Manabí to undertake the introduction of local development models in the energy profile has highlighted. The realization of the territorial planning process from the local level can contribute to the adequate use of endogenous resources, reduce the dependence of some territories to others, unleash the culture of energy entrepreneurship, stimulate small business, promote social and solidarity cooperation, increase the equity, reduce poverty, raise environmental protection and ensure the good living of Ecuadorian society. 
Conflict of interest statement and funding sources

The authors declared that they have no competing interest.

Statement of authorship

The authors have a responsibility for the conception and design of the study. The authors have approved the final article.

Acknowledgments

The authors would like to thank the Editor of IRJMIS for their valuable time, support, and advice in completing the current study.

Pérez, A. V., Viteri, C. G. F. V., Gámez, M. R., \& Ramos, J. L. M. (2019). Local development applied to energy scheme. International Research Journal of Management, IT and Social Sciences, 6(5), 9-16.

https://doi.org/10.21744/irjmis.v6n5.657 


\section{References}

Anglada-Escudé, G., Amado, P. J., Barnes, J., Berdiñas, Z. M., Butler, R. P., Coleman, G. A., ... \& Jeffers, S. V. (2016). A terrestrial planet candidate in a temperate orbit around Proxima Centauri. Nature, 536(7617), 437.

Belmonte, S., Franco, J., Viramonte, J., \& Nuñez, V. (2009). Integration of renewable energies in territorial planning processes. Advances in Renewable Energy and Environment , 13, 07-41.

Cedeno, M. L. D., Arteaga, M. G. D., Perez, A. V., \& Arteaga, M. L. D. (2017). Regulatory framework for renewable energy sources in Ecuador case study province of Manabi. International Journal of Social Sciences and Humanities, 1(2), 29-42. https://doi.org/10.29332/ijssh.v1n2.33

Chilán, J. C. H., Torres, S. G. P., Machuca, B. I. F., Cordova, A. J. T., Pérez, C. A. M., \& Gamez, M. R. (2018). Social impact of renewable energy sources in the province of Loja. International Journal of Physical Sciences and Engineering, 2(1), 13-25. https://doi.org/10.29332/ijpse.v2n1.79

Constituent Assembly. (2008). Constitution of the Republic of Ecuador. Government of Ecuador.

Daily The Telegraph. (2016). The economic wealth of Manabi is centered on agriculture, fishing and tourism. https://www.eltelegrafo.com.ec/noticias/ecuador/3/la-riqueza-economica-de-manabi-se-centra-en-la-agriculturala-pesca-y-el-turismo

GADP (2014). Provincial government of Manabí, 2014 annual operating plan http://www.manabi.gob.ec/images2010/2015/03/POA-2014_Planteamiento-Estrategico.pdf

Gámez, M. R., Pérez, A. V., \& Arauz, M. S. (2017). EJE 06-06 La ordenación territorial y las fuentes renovables de energía. Memorias Universidad del Azuay, (XVI), 287-292.

Gámez, M. R., Pérez, A. V., Wilber, M., \& Guardarrama, J. R. (2017). El Potencial Solar y la Generación Distribuida en la Provincia de Manabí en el Ecuador. Revista de Investigaciones en Energía, Medio Ambiente y Tecnología: RIEMAT ISSN: 2588-0721, 2(2), 41-45.

Gamez, MR, Perez, AV, Sera, AS, \& Ronquillo, ZM (2017). Renewable energy sources and local development. International Journal of Social Sciences and Humanities , $1 \quad$ (2), 10 19. https://doi.org/10.29332/ijssh.v1n2.31

IICA. (2015). Inter-American Institute for Cooperation on Agriculture. Piñón Project in Ecuador - Galapagos the great beneficiary. Retrieved from the IICA website: https://www.iica.int/en/press/news/projectpi\%C3\%B1\%C3\%B3n-en-ecuador-gal\%C3\%A1pagos-el-gran-beneficiario

Ilizástigui Dupuy, F., \& Rodríguez Rivera, L. (2017). The clinical method Journal of Non-Communicable Diseases Finlay , 7 (1), 2-11.

INEC (2016). National Institute of Statistics and Census. Survey of Surface and Continuous Agricultural Production. http://www.ecuadorencifras.gob.ec/documentos/webinec/Estadisticas_agropecuarias/espac/espac2016/Presentaci on\%20ESPAC\%202016.pdf

Irusta, LA (2016). Renewable energies in the territorial order Magazine Linking Sustainable Development + Personal Development (http://vinculando.org).

MEER (2014). Ministry of Electricity and Renewable Energies. Atlas of the Ecuadorian Electrical Sector 2014. Quito: Agency for Regulation and Control of Electricity 2014, ISBN: 9789942079480 (http://biblioteca.udla.edu.ec/client/es_EC).

Meza, A. K. T., Freyre, J. R. A., Cevallos, M. G. O., \& Pico, M. J. M. (2018). Autonomy, Good Humor and Support Networks, Potential of Community Resilience Intervention in People Victims of the Earthquake in the Calderón Parish. International Research Journal of Management, IT and Social Sciences, 5(1), 1-8.

Muentes, S. A. G., Ávila, M. G. G., Vázquez, B. L. L., \& del Campo Laffita, A. E. S. (2017). The production of biodiesel from jatropha curca and its social impact. International research journal of engineering, IT \& scientific research, 3(6), 89-98.

Perez, A. V., Gamez, M. R., Viteri, C. G. V., \& Quiroz, A. M. V. (2017). Community power as a driving force for sustainable local development. International Research Journal of Engineering, IT \& Scientific Research, 3(4), 819. 